\title{
Impacts of elevated ozone on growth and photosynthesis of Metasequoia glyptostroboides Hu et Cheng
}

\author{
Weiwei Zhang a,b ${ }^{\text {, Zhaozhong Feng }}{ }^{\mathrm{a}, *}$, Xiaoke Wang ${ }^{\mathrm{a}}$, Junfeng Niu ${ }^{\mathrm{a}}$ \\ a State Key Laboratory of Urban and Regional Ecology, Research Center for Eco-Environmental Sciences, Chinese Academy of Sciences, 18 Shuangqing Road, \\ Haidian District, Beijing 100085, China \\ ${ }^{\mathrm{b}}$ Key Laboratory of Mollisols Agroecology, Northeast Institute of Geography and Agroecology, Chinese Academy of Sciences, Harbin 150081, China
}

\section{A R T I C L E I N F O}

\section{Article history:}

Available online 13 June 2014

\section{Keywords:}

Growth

Metasequoia glyptostroboides

Ozone

Photosynthesis

Living fossil species

\begin{abstract}
A B S T R A C T
One-year-old Metasequoia glyptostroboides seedlings were exposed to non-filtered ambient air (NF) and elevated ozone $\left(\mathrm{E}-\mathrm{O}_{3}, \mathrm{NF}+60 \mathrm{ppb}\right)$ in open-top chambers for two years. $\mathrm{E}^{-} \mathrm{O}_{3}$ accelerated leaf senescence, as indicated by significant decreases in photosynthetic pigment contents with the elongation of $\mathrm{O}_{3}$ exposure. $\mathrm{E}-\mathrm{O}_{3}$ significantly affected gas exchange and carboxylation, inducing reductions in light-saturated photosynthesis $\left(A_{\text {sat }}\right)$, the maximum activity of Rubisco $\left(V_{c, \max }\right)$ and the maximum electron transport rate $\left(J_{\max }\right)$. Chl a/b, $V_{c, \max } / J_{\max }$ and stomatal limitation $(l)$ were not affected. Stomatal conductance $\left(g_{\mathrm{s}}\right)$ was significantly decreased by $\mathrm{E}^{-} \mathrm{O}_{3}$ in the first year, but remained unchanged in the second year. It can be inferred that the decrease in $A_{\text {sat }}$ by E-O $\mathrm{O}_{3}$ was mainly attributed to the changes in non-stomatal factors. After two years' exposure, $\mathrm{E}-\mathrm{O}_{3}$ caused significant decreases in canopy photosynthesis and leaf mass per area, and a significant increase in the number of branches, but induced slight, not significant decreases in growth and biomass. Therefore, it can be concluded that the carbon accumulation of the species $M$. glyptostroboides could be negatively affected after long-term exposure to high $\mathrm{O}_{3}$ concentration.
\end{abstract}

(C) 2014 Elsevier Ireland Ltd. All rights reserved.

\section{Introduction}

Ground-level ozone $\left(\mathrm{O}_{3}\right)$ is considered to be the most relevant air pollutant causing acute and/or chronic damages to trees in the Northern Hemisphere, and in particular in East Asia[1-3], where a rapid increase in the emission of the main critical ozone precursors such as $\mathrm{NO}_{x}$ and volatile organic compounds (VOCs) has been observed. Due to increasing biogenic VOCs emissions over East China under the projected climate scenarios (2000-2050), increases in both surface $\mathrm{O}_{3}$ concentration and high $\mathrm{O}_{3}$ episodes are expected to occur [4]. Such current and future $\mathrm{O}_{3}$ levels may pose a risk to subtropical tree species in this region.

Several studies have shown that, in northern temperate woody species, current and elevated $\mathrm{O}_{3}$ concentrations induce significant reductions in photosynthesis $[5,6]$ and shifts in carbon allocation $[2,7]$. For conifer or needle plants, $\mathrm{O}_{3}$-induced reductions in photosynthesis have been reported for Norway spruce (Picea abies) $[8,9]$ and different pine species such as ponderosa pine (Pinus

\footnotetext{
* Corresponding author at: Research Center for Eco-Environmental Sciences, Chinese Academy of Sciences, 18 Shuangqing Road, Haidian District, Beijing 100085, China. Tel.: +8610 62943823; fax: +861062943822.

E-mail addresses: zhzhfeng201@hotmail.com, fzz@rcees.ac.cn (Z. Feng).
}

ponderosa) $[10,11]$, Scots pine (Pinus sylvestris) [12,13] and loblolly pine (Pinus taeda) [14]. Among the various responses of tree species to $\mathrm{O}_{3}$, decreases in chlorophyll content and in stomatal conductance $\left(g_{s}\right)$, leading to a decline in photosynthesis, have been commonly observed $[3,15]$. However, in some cases, $\mathrm{O}_{3}$-induced changes in $g_{s}$ are insufficient to explain the decline in light-saturated photosynthesis $\left(A_{\text {sat }}\right)$ [16]. Reductions in $A_{\text {sat }}$ have been attributed to decreases in primary carboxylation enzyme Rubisco transcript levels, antioxidant contents and enzyme activity rather than changes in $g_{s}[17,18]$. A recent study suggests that elevated $\mathrm{O}_{3}$ induces faster rates of change in photosynthesis rate compared to $g_{s}$ because of the significant decrease in the maximum activity of Rubisco $\left(V_{c, \max }\right)$ and maximum electron transport rate $\left(J_{\max }\right)$, i.e., $\mathrm{O}_{3}$ reduces the biochemical capacity to fix $\mathrm{CO}_{2}$ [19].

The review of the effects of current and projected $\mathrm{O}_{3}$ on biomass, growth, foliar physiology and biochemistry of trees using a meta-analyses approach concluded that current ambient $\mathrm{O}_{3}$ concentration ( $40 \mathrm{ppb}$ on average) significantly reduced the total biomass of trees by $7 \%$ compared with trees grown in charcoalfiltered $(\mathrm{CF})$ air, while elevated $\mathrm{O}_{3}(64 \mathrm{ppb})$ reduced total biomass by $11 \%$ compared with trees grown at current ambient $\mathrm{O}_{3}$ concentration [20]. Furthermore, gymnosperms were less sensitive to than angiosperms [16], and the reduction in total biomass of gymnosperm species was largely driven by significant decreases in root 
Table 1

Daily 8-h (8:00-16:00) averaged $\mathrm{O}_{3}$ concentration and AOT40 (the cumulative $\mathrm{O}_{3}$ exposure over a threshold of the 1 -h average $\left[\mathrm{O}_{3}\right]$ of $40 \mathrm{ppb}$ ) value for non-filtered (NF) and elevated ozone $\left(\mathrm{E}-\mathrm{O}_{3}\right)$ treatments at two growing seasons.

\begin{tabular}{|c|c|c|c|c|}
\hline \multirow[t]{2}{*}{ Years } & \multicolumn{2}{|l|}{2009} & \multicolumn{2}{|l|}{2010} \\
\hline & $\mathrm{NF}$ & $\mathrm{E}-\mathrm{O}_{3}$ & $\mathrm{NF}$ & $\mathrm{E}-\mathrm{O}_{3}$ \\
\hline The maximum daily $8-\mathrm{h} \mathrm{O}_{3}$ (ppb) & 81.5 & 169.6 & 73.2 & 136.7 \\
\hline The minimum daily $8-\mathrm{h} \mathrm{O}_{3}(\mathrm{ppb})$ & 14.9 & 70.1 & 9.2 & 62.9 \\
\hline Daily 8-h mean (ppb) & 37.0 & 54.6 & 34.9 & 53.9 \\
\hline AOT40 (ppm.h) & 2.9 & 20.7 & 3.2 & 28.9 \\
\hline
\end{tabular}

biomass [20]. Elevated $\mathrm{O}_{3}$ can induce a shift in the resource allocation into height growth at the expense of diameter growth [9]. Furthermore, $\mathrm{O}_{3}$ can also cause shift in carbon allocation away from roots [21,22], and often associated with decreased root/shoot ratio $[23,24]$. Unfortunately, there is little information on the biomass production and allocation of subtropical deciduous trees exposed to higher $\mathrm{O}_{3}$ concentration.

Metasequoia glyptostroboides, commonly known as dawn redwood or Chinese redwood, is a "living fossil" discovered as a relict population in a remote area near the border of Sichuan in SouthCentral China in the 1940s [25]. In view of its esthetic beauty and economical value as a potential source of wood for forest products, this species with softy and feathery leaves has been widely naturalized for greening and ornamental plantings in cities from southeast China. The $\mathrm{O}_{3}$ sensitivity of $M$. glyptostroboides has previously been studied in open top chambers, showing that acute $\mathrm{O}_{3}$ exposure at both 100 and $200 \mathrm{ppb}$ for 25 days ( $8 \mathrm{~h}$ per day fumigation) significantly reduced net photosynthetic rate, $g_{s}$, leaf length and crown width, compared to charcoal-filtered air $(\mathrm{CF}<15 \mathrm{ppb})$ [26]. To extend further, this study investigated the pigment content, photosynthesis mechanism and growth of M. glyptostroboides in response to chronic $\mathrm{O}_{3}$ exposure during two growing seasons. The aims of this study are (1) to assess whether elevated $\mathrm{O}_{3}$ concentration in the near future will negatively affect foliar photosynthesis and growth in this species, and (2) to determine the mechanism explaining the observed ozone-induced reduction in $A_{\text {sat }}$, taking into account $g_{s}, V_{c, \max }$ and $J_{\max }$.

\section{Materials and methods}

\subsection{Experimental site and plant material}

One-year-old seedlings of $M$. glyptostroboides were obtained from commercial nurseries and individually transplanted into $6 \mathrm{~L}$ circular plastic pots filled with native yellowish brown lateritic soil (soil organic C $0.98 \%$, total $\mathrm{N} 1.36 \mathrm{~g} \mathrm{~kg}^{-1}$, total P $0.27 \mathrm{~g} \mathrm{~kg}^{-1}$, total $\mathrm{K} 1.41 \%$ ) in mixture with litter collected under firry forest at the ratio of $1: 1(\mathrm{v} / \mathrm{v})$. From November 2008 until the middle of April 2009 , all seedlings were cultivated in a temperature controlled and double glazed greenhouse $\left(25 \pm 2{ }^{\circ} \mathrm{C}\right.$, air relative humility $\left.70-90 \%\right)$ in Ningbo, Zhejiang Province, China. After then, the seedlings with similar height and basal diameter were selected and moved to the experimental site which was located at the Tiantong National Field Observation and Research Station for Subtropical Forest Ecosystems $\left(29^{\circ} 48^{\prime} \mathrm{N}, 121^{\circ} 47^{\prime} \mathrm{E}\right)$. At the beginning of the experiment, stem height and stem basal diameter in two directions at $5 \mathrm{~cm}$ of stem height were measured for each seedling. The saplings were about $40-50 \mathrm{~cm}$ tall and pre-adapted to open-top chambers (OTCs, octagonal base, $7 \mathrm{~m}^{2}$ of growth space and $2.6 \mathrm{~m}$ in height) condition for two weeks before $\mathrm{O}_{3}$ fumigation. During the cultivation and ozone exposure, plants were well watered with tap water to avoid drought stress.
Table 2

Analysis of variance of the effects of $\mathrm{O}_{3}$ treatment, days after fumigation (DAF) and their interactions on the variables in $M$. glyptostroboides seedlings exposed to elevated $\mathrm{O}_{3}$ concentration for two growing seasons.

\begin{tabular}{|c|c|c|c|c|c|c|}
\hline & \multicolumn{3}{|l|}{2009} & \multicolumn{3}{|l|}{2010} \\
\hline & $\mathrm{O}_{3}$ & DAF & $\mathrm{O}_{3} \times \mathrm{DAF}$ & $\mathrm{O}_{3}$ & DAF & $\mathrm{O}_{3} \times \mathrm{DAF}$ \\
\hline Total chl & $<0.0001$ & $<0.0001$ & 0.004 & $<0.0001$ & $<0.0001$ & 0.012 \\
\hline Car & $<0.0001$ & $<0.0001$ & 0.001 & $<0.0001$ & 0.010 & 0.133 \\
\hline Chl a/b & 0.163 & $<0.0001$ & 0.587 & 0.699 & $<0.0001$ & 0.191 \\
\hline$A_{\text {sat }}$ & $<0.0001$ & 0.062 & 0.345 & $<0.0001$ & $<0.0001$ & 0.345 \\
\hline$g_{s}$ & 0.001 & $<0.0001$ & 0.165 & 0.145 & $<0.0001$ & 0.624 \\
\hline$C_{\mathrm{i}}$ & 0.285 & $<0.0001$ & 0.143 & 0.020 & $<0.0001$ & 0.985 \\
\hline$V c_{\max }$ & $<0.0001$ & $<0.0001$ & 0.476 & 0.021 & $<0.0001$ & 0.615 \\
\hline$J_{\max }$ & 0.002 & $<0.0001$ & 0.381 & 0.022 & $<0.0001$ & 0.848 \\
\hline$V_{\mathrm{c}, \max } / J_{\max }$ & 0.415 & 0.003 & 0.875 & 0.453 & 0.010 & 0.131 \\
\hline$l$ & 0.963 & $<0.0001$ & 0.292 & 0.589 & $<0.0001$ & 0.981 \\
\hline
\end{tabular}

\subsection{Fumigation}

There were two $\mathrm{O}_{3}$ treatments: non-filtered ambient air (NF) and $\mathrm{NF}+60 \mathrm{ppb} \mathrm{O}_{3}\left(\mathrm{E}-\mathrm{O}_{3}\right)$, with two chamber replicates per treatment. The selected seedlings were enclosed in OTCs, which were randomly used as control and $\mathrm{O}_{3}$ treatment in the field. The averaged air velocity in each chamber corresponded to approximately two complete air exchange per minute. For $\mathrm{E}-\mathrm{O}_{3}, \mathrm{O}_{3}$ was generated from pure oxygen by an electrical discharge $\mathrm{O}_{3}$ generator (HY003, Chuangcheng Co. Jinan, China) and then mixed with ambient air to achieve the target $\mathrm{O}_{3}$ concentration. The $\mathrm{O}_{3}$ concentration in the OTCs was continuously monitored at approximately $10 \mathrm{~cm}$ above plant canopy using a UV absorption $\mathrm{O}_{3}$ analyzer (Model 49iThermo, USA).

For each treatment, seedlings were transposed into two fumigation chambers with 10 plants per chamber. The position of plants was changed every 5-7 days within each OTC to eliminate positional effects. Every 10-15 days, the chambers were emptied and randomly reassigned to two target $\mathrm{O}_{3}$ level, and the seedlings were replaced back according to their specified treatment levels. The fumigation periods were from 25 May to 10 September 2009, and 2 May to 12 September 2010 with a daily maximum of $8 \mathrm{~h}$ (from 08:00 to 16:00) when there was no rain, fog, mist or dew. There were totally 56 and 75 effective fumigation days during 2009 and 2010 growing seasons, respectively. During the fumigation period in 2010 growing season, mean air temperature and relative air humidity inside and outside the OTCs were $25.2^{\circ} \mathrm{C}$ and $24.9{ }^{\circ} \mathrm{C}$, and $81.8 \%$ and $88.2 \%$, respectively, while the maximum air temperature and relative air humidity were $32.7^{\circ} \mathrm{C}$ and $31.8^{\circ} \mathrm{C}$, and $99.0 \%$ and $93.6 \%$, respectively.

Table 3

Height increments ( $\mathrm{cm}$ ), basal diameter increments ( $\mathrm{mm}$ ), branch increments (number), and carbon accumulation and distribution in $M$. glyptostroboides seedlings exposed to elevated $\mathrm{O}_{3}$ concentration for two growing seasons.

\begin{tabular}{|c|c|c|c|}
\hline & $\mathrm{NF}$ & $\mathrm{E}-\mathrm{O}_{3}$ & $P$ value \\
\hline Height increments (cm) & $43.4 \pm 8.3$ & $40.6 \pm 8.2$ & 0.367 \\
\hline $\begin{array}{l}\text { Basal diameter increments } \\
\quad(\mathrm{mm})\end{array}$ & $5.54 \pm 1.18$ & $5.17 \pm 1.35$ & 0.427 \\
\hline $\begin{array}{l}\text { Branch increments } \\
\left.\quad \text { (number plant }^{-1}\right)\end{array}$ & $14.2 \pm 5.6$ & $21.5 \pm 7.2$ & 0.004 \\
\hline Total biomass ( g plant $^{-1}$ ) & $144.47 \pm 15.65$ & $135.02 \pm 19.44$ & 0.538 \\
\hline Leaf mass ( g plant $^{-1}$ ) & $32.75 \pm 3.93$ & $30.35 \pm 5.80$ & 0.280 \\
\hline Stem mass ( g plant $^{-1}$ ) & $43.57 \pm 4.77$ & $41.36 \pm 5.32$ & 0.215 \\
\hline Root mass (g plant ${ }^{-1}$ ) & $68.15 \pm 8.65$ & $63.30 \pm 11.33$ & 0.373 \\
\hline Root/above-ground & $0.892 \pm 0.061$ & $0.885 \pm 0.134$ & 0.823 \\
\hline
\end{tabular}




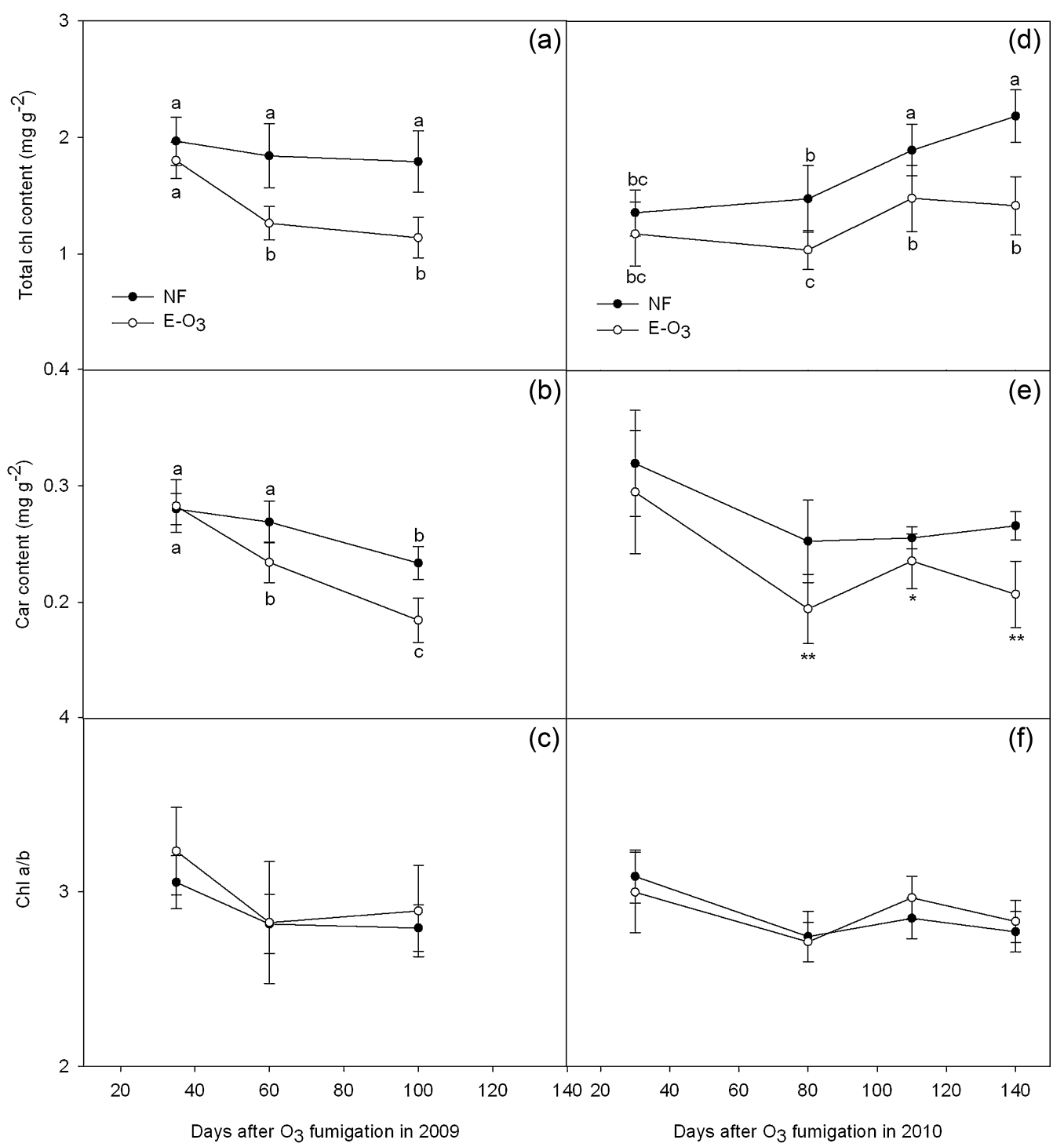

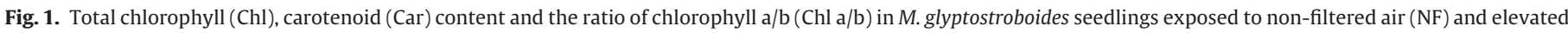

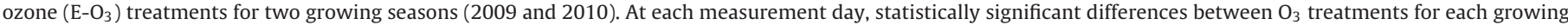
season are noted with an asterisk at $P<0.05$. Error bars represent SD of the means $(N=8)$.

\subsection{Leaf gas exchange and canopy photosynthesis measurements}

Gas exchange was measured on fully expanded leaves from the upper part of the canopy with a portable photosynthesis system fitted with a red/blue LED light source (LI-6400, LI-COR Inc. Lincoln, NE, USA). The system controlled saturating PPFD (photosynthetic photon flux density) at $1200 \mu \mathrm{mol} \mathrm{m}{ }^{-2} \mathrm{~s}^{-1}$. The block temperature was set to the ambient average of $33^{\circ} \mathrm{C}, \mathrm{CO}_{2}$ at $380 \mu \mathrm{mol} \mathrm{mol}{ }^{-1}$, and relative humidity ( $\mathrm{RH}$ ) at 50-65\%. All measurements were conducted during 09:00-11:00 and recorded when the stability, or steady state indicated by total coefficient of variation, was $\leq 3 \%$. Since the leaf was not large enough to fill in the red/blue LED light source chamber, the enclosed leaf was cut and its area was measured with a Li-Cor 3000 leaf area meter (Li-Cor, Lincoln, NE, USA), just after gas exchange measurement.

During the experiment, $\mathrm{A} / C_{\mathrm{i}}$ curves were performed on upper leaves of two different plants per OTC with two OTCs replicates using the automatic program in the LI-6400 photosynthesis system. When $g_{s}$ reached equilibrium, subsequent measurements were made following step-wise changes in reference $\mathrm{CO}_{2}$ concentration: $380,300,200,100,50,150,250,400,600,900,1200$, $1500 \mu \mathrm{mol} \mathrm{mol}^{-1}$, under PPFD of $1200 \mu \mathrm{mol} \mathrm{m}^{-2} \mathrm{~s}^{-1}$, block temperature of $32 \pm 0.5^{\circ} \mathrm{C}$ and relative humidity of $50-70 \% . V_{c, \max }$ and $J_{\max }$ and were derived by iteratively fitting curves to $\mathrm{A} / C_{\mathrm{i}}$ response data according to the program of Sharkey et al. [27], as described by Long and Bernacchi [28]. Stomatal limitation $(l)$ was calculated as $l=1-A_{C_{\mathrm{a}} 380} / A_{C_{\mathrm{i}} 380}$, where $A_{C_{\mathrm{a}} 380}$ and $A_{C_{\mathrm{i}} 380}$ represent net $\mathrm{CO}_{2}$ assimilation rate at $C_{\mathrm{a}}=380 \mathrm{ppm}$ and at $C_{\mathrm{i}}=380 \mathrm{ppm}$, respectively.

Canopy photosynthesis (CP) was measured at the end of fumigation using a system consisting of a chamber, $\mathrm{CO}_{2}$ analyzers ( $\mathrm{Li}-840$ $\mathrm{CO}_{2} / \mathrm{H}_{2} \mathrm{O}$, Li-Cor, Inc, USA), air pump, desiccant and filter. The chamber was framed by aluminum pipes $(40 \mathrm{~cm} \times 40 \mathrm{~cm}$ square base, $1.2 \mathrm{~m}$ in height) and covered with transparent plastic film. During the measurements, the chamber was placed on a square base through water to make the system airtight. And the air inside the chamber was homogenized by two fans installed inside at $60 \mathrm{~cm}$ above the base. When the air $\mathrm{CO}_{2}$ concentration showed a steady state and reached $500 \mathrm{ppm}$, the $\mathrm{CO}_{2}$ value, air temperature $(T)$ and relative humidity inside the chamber were monitored and recorded for $10 \mathrm{~min}$ at $10 \mathrm{~s}$ intervals. Just a few days after the measurement 


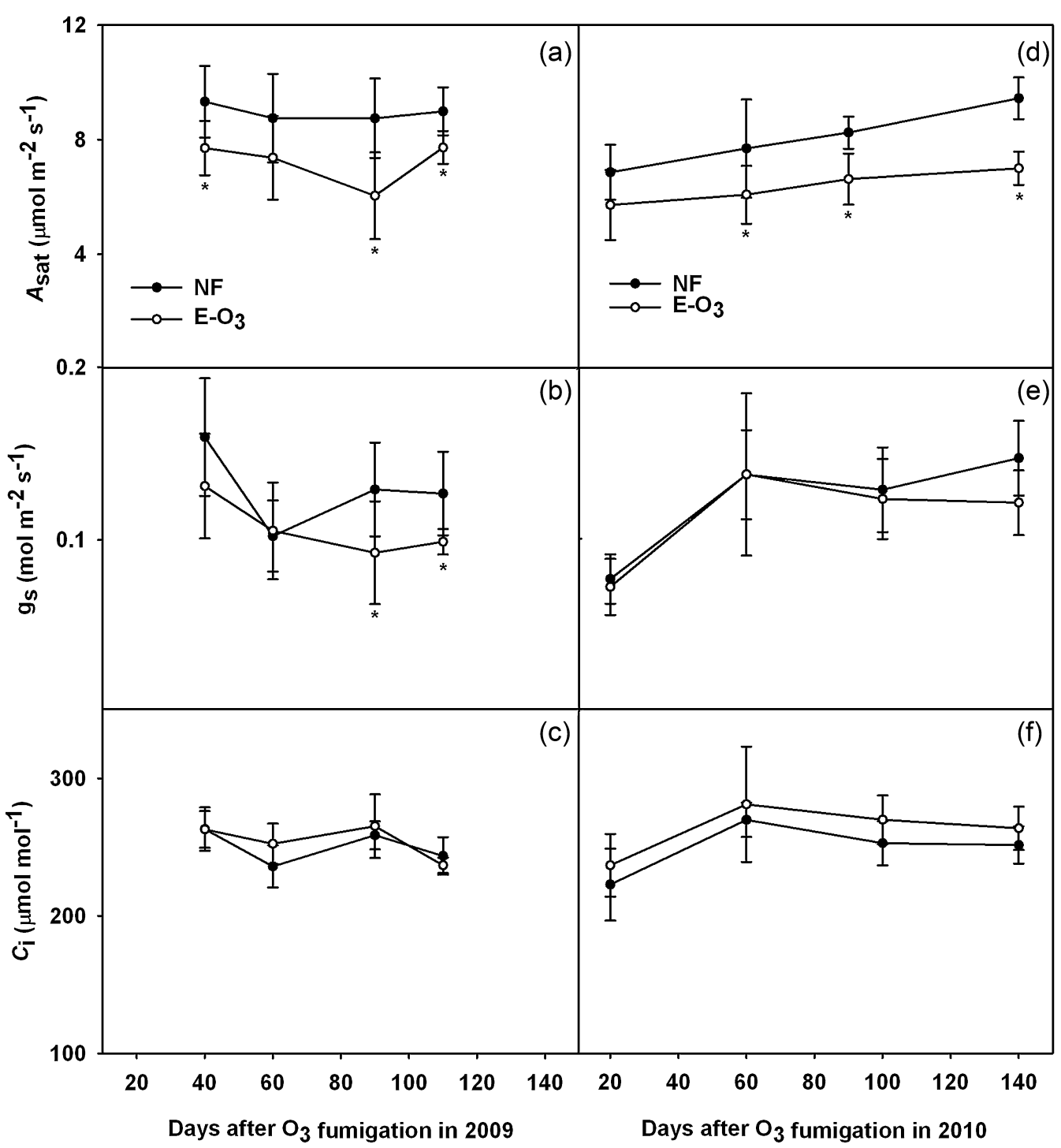

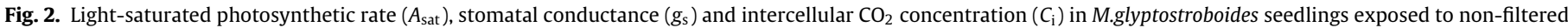

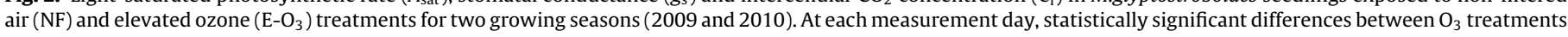
for each growing season are noted with an asterisk at $P<0.05$. Error bars represent SD of the means $(N=8)$.

of canopy photosynthesis, all leaves of the plant were harvested to determine the biomass and leaf area.

The canopy photosynthesis was calculated as:

$\mathrm{CP}=\left(\frac{\Delta c}{\Delta t}\right) \times\left(\frac{V}{22.4}\right) \times\left[\frac{273 /(273+T)}{S}\right]$

where CP is canopy photosynthesis $\left(\mu \mathrm{mol} \mathrm{CO}_{2} \mathrm{~m}^{-2} \mathrm{~s}^{-1}\right), \Delta t$ is $10 \mathrm{~s}$ intervals, $\Delta c$ is the decreased value of $\mathrm{CO}_{2}$ concentration during $10 \mathrm{~s}$ intervals ( $\mu \mathrm{mol} \mathrm{mol}^{-1}$ ), $V$ is volume in the chamber $\left(\mathrm{m}^{3}\right)$; $S$ is canopy leaf area $\left(\mathrm{m}^{2}\right)$, and $T$ is air temperature inside chamber $\left({ }^{\circ} \mathrm{C}\right)$.

\subsection{Pigments content}

About $0.1 \mathrm{~g}$ of leaves from three plants from each OTC were extracted with $4 \mathrm{ml} \mathrm{95 \%} \mathrm{ethanol} \mathrm{in} \mathrm{the} \mathrm{dark} \mathrm{for} 48 \mathrm{~h}$ at $4{ }^{\circ} \mathrm{C}$. The absorbance of leaf pigment extracts was measured at 646, $663 \mathrm{~nm}$ and $470 \mathrm{~nm}$. Total chlorophyll (Chl) and carotenoid (Car) content were calculated according to the specific absorption coefficients provided by Lichtenthaler [29].

\subsection{Growth and biomass production}

At the end of the experiment, the area of 30 unwrinkled and undamaged leaves per plant was measured with a Li-Cor 3000 leaf area meter, and dry mass was determined after oven-drying at $80^{\circ} \mathrm{C}$ until a constant weight in order to calculate leaf mass per area (LMA). All seedlings were harvested and separated into leaves, stems and roots. Dry mass was determined after oven-drying at $80^{\circ} \mathrm{C}$ until a constant weight. The canopy leaf area was calculated as $\mathrm{S}=$ leaf mass/LMA.

\subsection{Statistical analysis}

In order to test the influence of chamber on measured variables, all data were firstly checked for normal distribution and homogeneity of variance, and then subjected to multivariate analysis of variance (MANOVA) using SPSS 16.0 software package for Windows. Since chamber-to-chamber variation within treatments was not significant, data for each dependent variable were subjected to the analysis of variance with mixed linear model (GLM) to test the effects of $\mathrm{O}_{3}$, exposure days and their interactions by Tukey's 


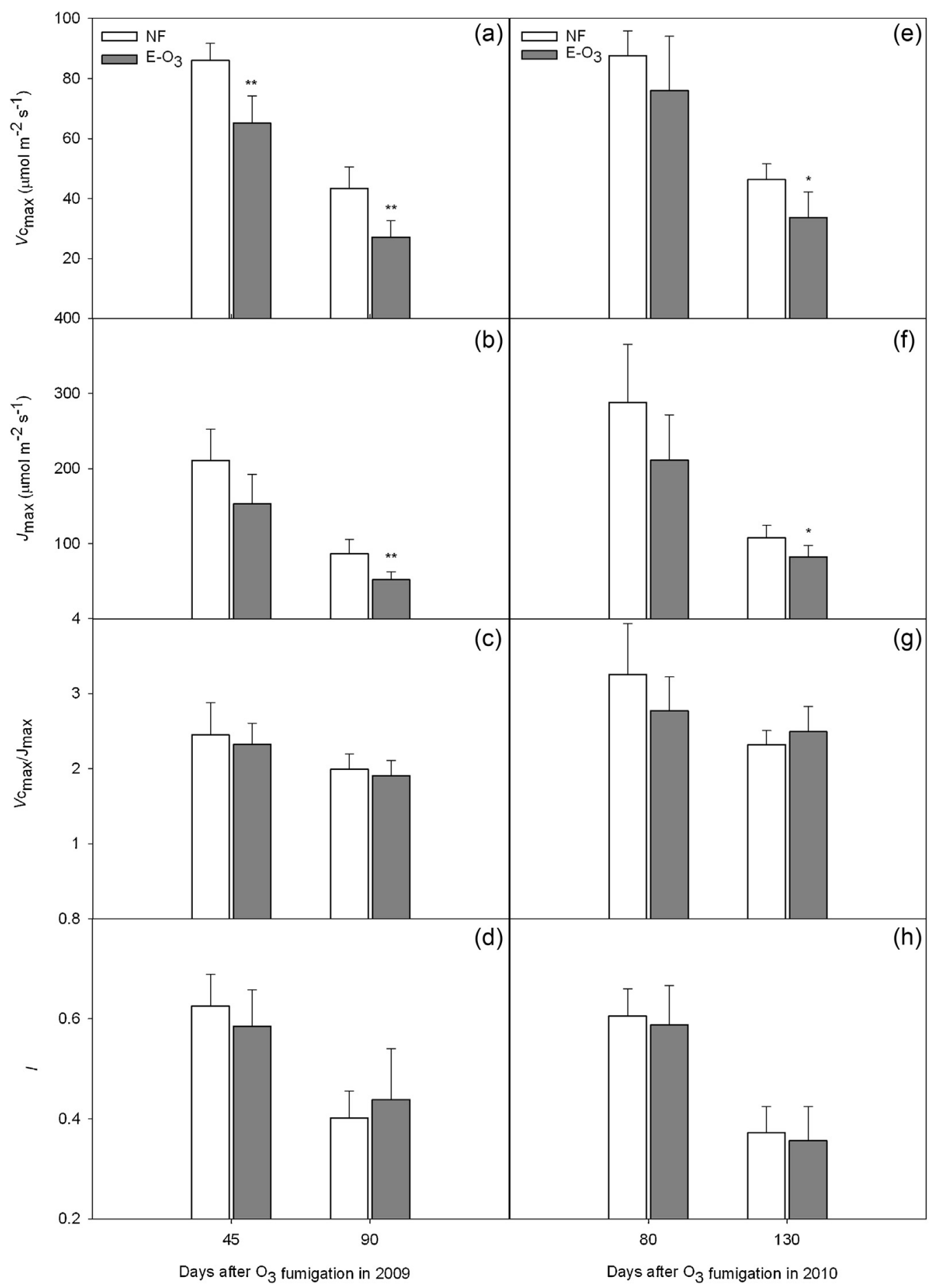

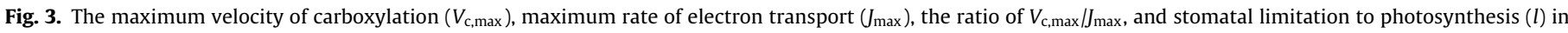

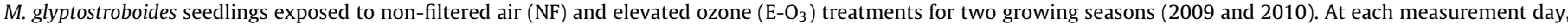
statistically significant differences between $\mathrm{O}_{3}$ treatments for each growing season are noted with an asterisk at $P<0.05$. Error bars represent SD of the means $(N=4)$.

HSD test, with eight or four plants as independent experimental units for each treatment. Student's- $t$ test was used to compare the means between $\mathrm{NF}$ and $\mathrm{E}-\mathrm{O}_{3}$ on individual measurement dates if there was significant $\mathrm{O}_{3}$ or interaction effect. Treatment effects were considered significant if $P<0.05$.

\section{Results}

Based on seasonal 8-h average $\mathrm{O}_{3}$ concentration (M8), the seedlings experienced similar $\mathrm{O}_{3}$ level in $\mathrm{E}-\mathrm{O}_{3}$ during both growing seasons (Table 1 ). The $\mathrm{O}_{3}$ concentration in $\mathrm{E}-\mathrm{O}_{3}$ was $48 \%$ and 54\% higher than that in NF in 2009 and 2010, respectively. $\mathrm{E}_{3} \mathrm{O}_{3}$ showed higher AOT40 values (AOT40, the cumulative $\mathrm{O}_{3}$ exposure over a threshold of the 1 -h average $\left[\mathrm{O}_{3}\right]$ of $40 \mathrm{ppb}$ ) in 2010 than in 2009 because the fumigation period in the former year was longer

Statistical analysis indicated that $\mathrm{E}-\mathrm{O}_{3}$ significantly reduced $\mathrm{Ch}$ and Car contents $(P<0.001)$ in both growing seasons, but it has no significant effect on $\mathrm{Chl} \mathrm{a/b}$ (Table 2). In the first year, significant reductions in $\mathrm{Chl}$ and Car contents by $\mathrm{E}-\mathrm{O}_{3}$ were observed after 60 days of fumigation (DAF), with an average decrease of $25 \%$ and 


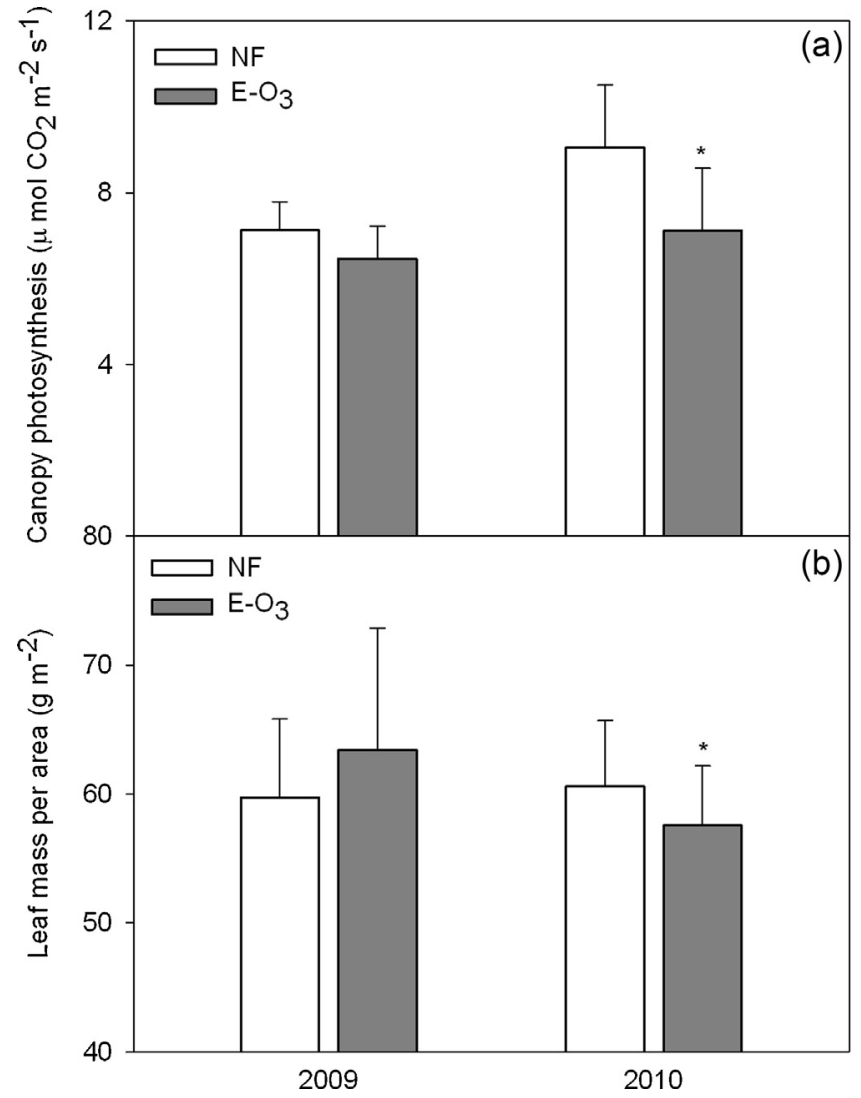

Fig. 4. Canopy photosynthesis (CP) and leaf mass per area (LMA) in M. glyptostroboides seedlings exposed to non-filtered air (NF) and elevated ozone $\left(\mathrm{E}-\mathrm{O}_{3}\right)$ treatments for two growing seasons (2009 and 2010). Statistically significant differences between $\mathrm{O}_{3}$ treatments for each growing season are noted with an asterisk at $P<0.05$. Error bars represent SD of the means $(N=4)$.

$11 \%$ during the whole growing season, respectively (Fig. $1 \mathrm{a}$ and $\mathrm{b}$ ). During the second year, similar reductions in Chl and Car contents (by $25 \%$ and $15 \%$ on average, respectively) were also observed in the $\mathrm{E}-\mathrm{O}_{3}$ treatment (Fig. $1 \mathrm{~d}$ and e).

ANOVA results indicated that $\mathrm{E}-\mathrm{O}_{3}$ significantly reduced $A_{\text {sat }}$ in both growing seasons, and affected $C_{\mathrm{i}}$ only at the second year (Table 2 ). In the first year, $\mathrm{E}-\mathrm{O}_{3}$ significantly decreased $A_{\text {sat }}$ by $17 \%$, $31 \%$ and $14 \%$ at 35,90 , and $110 \mathrm{DAF}$, respectively, compared to NF (Fig. 2a). Furthermore, E- $\mathrm{O}_{3}$ significantly decreased $g_{s}$ by $28 \%$ and $22 \%$ at 90 and 110 DAF, respectively (Fig. 2b). In the second year, E- $\mathrm{O}_{3}$ significantly decreased $A_{\text {sat }}$ since $60 \mathrm{DAF}(P<0.05)$, with a maximum decrease of $26 \%$ and $18 \%$ for $A_{\text {sat }}$, respectively, compared to $\mathrm{NF}$ (Fig. 2d). On the other hand, $C_{\mathrm{i}}$ was not affected by E- $\mathrm{O}_{3}$ at any measurement time, although a slight non-significant increase was observed across four measurements in the second year (Fig. 2f).

E- $O_{3}$ significantly impaired $V_{c, \max }$ and $J_{\max }$ (Table 2 ), as indicated that a magnitude of decrease increased progressively each year as leaves aged (Fig. 3). However, $\mathrm{E}^{-} \mathrm{O}_{3}$ had no effects on $V_{\mathrm{c}, \max } / J_{\max }$ and stomatal limitation (l) in both growing seasons (Fig. 3c, d, g, h). In the first year, at $90 \mathrm{DAF}, \mathrm{E}-\mathrm{O}_{3}$ significantly decreased $V_{\mathrm{c} \text {,max }}$ and $J_{\max }$ by $37 \%$ and $40 \%$, respectively (Fig. $3 \mathrm{a}$ and b). In the second year, similar negative effects on $V_{\mathrm{c}, \max }$ and $J_{\max }$ were observed: $V_{\mathrm{c} \text {, max }}$ decreased significantly by $27 \%$ and $J_{\max }$ by $24 \%$ (Fig. 3e and $\mathrm{f}$ ).

In 2009, ${\mathrm{E}-\mathrm{O}_{3}}_{3}$ had no significant effects on CP and LMA (Fig. 4). However, after two years of $\mathrm{O}_{3}$ fumigation, $\mathrm{CP}$ and LMA decreased significantly by $21 \%$ and $5 \%$, respectively, in $\mathrm{E}-\mathrm{O}_{3} . \mathrm{E}-\mathrm{O}_{3}$ caused slight, not significant decreases in height and basal diameter increments, whereas the number of branches significantly increased $(P<0.05$, Table 3$)$. Furthermore, $\mathrm{E}-\mathrm{O}_{3}$ had no significant effects on leaf, stem, root and total biomass and thus the ratio of root and above-ground biomass (Table 3 ).

\section{Discussion}

Further increases in ground-level $\mathrm{O}_{3}$ concentration is predicted in East Asian regions due to rapid economic growth. Several studies on native species in Asia reported that $\mathrm{O}_{3}$ caused visible leaf injury, reduced carbon assimilation, and limited the growth of trees (e.g., Cyclobalanopsis glauca and Fagus crenata [30,31]). In this study, $\mathrm{E}_{-} \mathrm{O}_{3}$ with $\mathrm{M} 8$ of $54 \mathrm{ppb}$ significantly caused changes in some photosynthetic parameters at leaf-level and canopy-level, e.g. pigment contents and net photosynthetic rate in both growing seasons, while two years' $\mathrm{O}_{3}$ fumigation did not affect biomass and $\mathrm{C}$ assimilate distribution of $M$. glyptostroboides. From the changes in these physiological parameters, it implied that two years' $\mathrm{O}_{3}$ fumigation significantly decreased the photosynthetic carbon gain at wholeplant level. This can be largely attributed to significant decreases in photosynthesis rate and pigments contents at leaf level rather than to changes in the total area of green leaves (LMA and leaf biomass to $\mathrm{E}-\mathrm{O}_{3}$ ).

In general, chronic $\mathrm{O}_{3}$ exposure resulted in stomatal closure, which is considered as the most important avoidance mechanisms to $\mathrm{O}_{3}$ stress $[17,32]$ because a decrease in $g_{s}$ protects trees from air pollution by decreasing $\mathrm{O}_{3}$ uptake [33]. In fact, in this study, leaves exhibited a significant decrease in $g_{s}$ in response to $\mathrm{E}-\mathrm{O}_{3}$ only at the end of the first growing season (Fig. 2). This is in agreement with a previous study on Arbutus unedo, a Mediterranean evergreen in which $\mathrm{O}_{3}$ did not significantly reduce midday steady-state $g_{s}$ compared to controls, but it slowed stomatal closure [34]. In addition, the response of $g_{s}$ to $\mathrm{E}-\mathrm{O}_{3}$ differed between the two growing seasons, while $g_{\mathrm{s}}$ considerably reduced in 2009, it remained unchanged in 2010 (Table 2 and Fig. 2). The $\mathrm{O}_{3}$ exposure induces an uncoupling of photosynthesis and stomatal conductance, as previously observed in three native tree species from China (Ailanthus altissima, Fraxinus chinensis and Platanus orientalis) [35]. Lombardozzi et al. [19] reported that the typical coupling of stomatal conductance and photosynthesis does not always hold under high $\mathrm{O}_{3}$ conditions, because $\mathrm{O}_{3}$ can directly affect the function of stomatal cells so that $g_{\mathrm{s}}$ no longer responds dynamically to changes in $C_{\mathrm{i}}$ and the rate of carboxylation due to enzyme and membrane damage. Unchanged $g_{s}$ with increased $C_{\mathrm{i}}$ in the second growing season, as observed in this study, indicated that the decrease in photosynthesis was independent of $g_{s}[15,36]$.

One possible explanation to the decreased net photosynthetic rate is related to the significant decreases in leaf-level $V_{c, \max }$ and $J_{\max }$ caused by $\mathrm{E}-\mathrm{O}_{3}$. Watanabe et al. [31] demonstrated that $\mathrm{O}_{3}$ significantly reduced the $V_{c, \max }$ and $J_{\max }$ in leaves of beech, but stomatal limitation of photosynthesis was unaffected by $\mathrm{O}_{3}$. Similar results were also found in some deciduous and evergreen species such as Liriodendron chinense and Cinnamomum camphora [17,37]. On the other hand, unchanged $l$ accompanied by a decrease in pigments content during the two-year study further confirmed that $\mathrm{O}_{3}$-induced the photosynthesis down-regulation was due to nonstomatal factors rather than stomatal closure. From the information above, the conifer species showed the similar mechanism on the reduced photosynthesis rate by high $\mathrm{O}_{3}$ concentration with evergreen or deciduous broadleaf species.

However, $\mathrm{E}-\mathrm{O}_{3}$ with AOT 40 of $50 \mathrm{ppm} \mathrm{h}$ (the sum of two seasons) had no significant effects on stem height and diameter increments, biomass accumulation and carbon distribution within plants, in spite of the significant decrease in canopy photosynthetic rate after two years fumigation (Table 3 ). These results suggest that whole 
plant growth could be negatively affected after a long-term $\mathrm{O}_{3}$ exposure.

M. glyptostroboides has an inherently LMA with an average value of $60 \mathrm{~g} \mathrm{~m}^{-2}$, similar to those $\mathrm{O}_{3}$-sensitive deciduous tree species [38], suggesting that $M$. glyptostroboides could be sensitive to $\mathrm{O}_{3}$. Bussotti [39] has pointed out that LMA was a better parameter to distinguish $\mathrm{O}_{3}$ sensitivity among species, and those species with some ecological characteristics such as low LMA and short leaf lifespan, high gas exchange rate and rapid growth rate, and favorable habitats are more sensitive to $\mathrm{O}_{3}$. In this study, the different response to $\mathrm{E}-\mathrm{O}_{3}$ between leaves and whole plants can be explained by short duration of effective fumigation ( 56 and 75 days in 2009 and 2010, respectively) and low $\mathrm{O}_{3}$ uptake due to partial stomatal closure at relatively high vapour pressure deficit (VPD) and temperature in typical summer days of subtropical climate. Moreover, E- $\mathrm{O}_{3}$ significantly increased the number of branches but not the stem biomass, suggesting that the length of branch could be reduced after $\mathrm{O}_{3}$ exposure (Table 3 ).

Overall, the results indicated that non-stomatal factors including decreased $\mathrm{Chl}$ and Car contents, $V_{\mathrm{c}, \max }$ and $J_{\max }$ accounted for the decrease in $A_{\text {sat }}$. Moreover, M. glyptostroboides apparently exhibited evident phenotypic plasticity, and similar decreases in root and above-ground in response to elevated $\mathrm{O}_{3}$ concentration, suggesting that root growth is as susceptible to $\mathrm{O}_{3}$ as the aboveground part.

\section{Acknowledgements}

This research was supported by Hundred Talent Program, Chinese Academy of Sciences, and the National Natural Science Foundation of China (No. 30700086 and No. 31200391 ). We express our appreciation to Dr. Vicent Calatayud for English improvement throughout the manuscript.

\section{References}

[1] A.H. Chappelka, L.J. Samuelson, Ambient ozone effects on forest trees of the eastern United States: a review, New Phytol. 139 (1998) 91-108.

[2] R. Matyssek, G. Wieser, R. Ceulemans, H. Rennenberg, H. Pretzsch, K. Haberer, M. Löw, A. Nunn, H. Werner, P. Wipfler, Enhanced ozone strongly reduces carbon sink strength of adult beech (Fagus sylvatica) - resume from the free-air fumigation study at Kranzberg Forest, Environ. Pollut. 158 (2010) 2527-2532.

[3] Y. Hoshika, Y. Shimizu, K. Omasa, A comparison between stomatal ozone uptake and AOT40 of deciduous trees in Japan, iForest 4 (2011) 128

[4] Y. Wang, L. Shen, S. Wu, L. Mickley, J. He, J. Hao, Sensitivity of surface ozone over China to 2000-2050 global changes of climate and emissions, Atmos. Environ. 75 (2013) 374-382

[5] K. Novak, P. Cherubini, M. Saurer, J. Fuhrer, J.M. Skelly, N. Kräuchi, M. Schaub, Ozone air pollution effects on tree-ring growth, $\delta^{13} \mathrm{C}$, visible foliar injury and leaf gas exchange in three ozone-sensitive woody plant species, Tree Physiol. 27 (2007) 941-949.

[6] L.D. Emberson, P. Büker, M.R. Ashmore, Assessing the risk caused by ground level ozone to European forest trees: a case study in pine, beech and oak across different climate regions, Environ. Pollut. 147 (2007) 454-466.

[7] B.S. Felzer, T. Cronin, J.M. Reilly, J.M. Melillo, X. Wang, Impacts of ozone on trees and crops, C R Geosci. 339 (2007) 784-798.

[8] T. Keller, R. Häsler, The influence of a fall fumigation with ozone on the stomatal behavior of spruce and fir, Oecologia 64 (1984) 284-286.

[9] H. Pretzsch, J. Dieler, R. Matyssek, P. Wipfler, Tree and stand growth of mature Norway spruce and European beech under long-term ozone fumigation, Environ. Pollut. 158 (2010) 1061-1070.

[10] J.A. Panek, A.H. Goldstein, Response of stomatal conductance to drought in ponderosa pine: implications for carbon and ozone uptake, Tree Physiol. 21 (2001) 337-344.

[11] N. Grulke, R. Alonso, T. Nguyen, C. Cascio, W. Dobrowolski, Stomata open at night in pole-sized and mature ponderosa pine: implications for $\mathrm{O}_{3}$ exposure metrics, Tree Physiol. 24 (2004) 1001-1010.

[12] A. Augustaitis, A. Bytnerowicz, Contribution of ambient ozone to Scots pine defoliation and reduced growth in the Central European forests: a Lithuanian case study, Environ. Pollut. 155 (2008) 436-445.
[13] M.S. Broadmeadow, S. Jackson, Growth responses of Quercus petraea, Fraxinus excelsior and Pinus sylvestris to elevated carbon dioxide, ozone and water supply, New Phytol. 146 (2000) 437-451.

[14] S. Anttonen, M.L. Sutinen, A.S. Heagle, Ultrastructure and some plasma membrane characteristics of ozone-exposed loblolly pine needles, Physiol. Plant. 98 (1996) 309-319.

[15] Ü Niinemets, Stomatal conductance alone does not explain the decline in folia photosynthetic rates with increasing tree age and size in Picea abies and Pinus sylvestris, Tree Physiol. 22 (2002) 515-535.

[16] V.E. Wittig, E.A. Ainsworth, S.P. Long, To what extent do current and projected increases in surface ozone affect photosynthesis and stomatal conductance of trees? A meta-analytic review of the last 3 decades of experiments, Plant Cell Environ. 30 (2007) 1150-1162.

[17] W.W. Zhang, J.F. Niu, X.K. Wang, Y. Tian, F.F. Yao, Z.Z. Feng, Effects of ozone exposure on growth and photosynthesis of the seedlings of Liriodendron chinense (Hemsl.) Sarg, a native tree species of subtropical China, Photosynthetica 49 (2011) 29-36.

[18] E.A. Ainsworth, C.R. Yendrek, S. Sitch, W.J. Collins, L.D. Emberson, The effects of tropospheric ozone on net primary productivity and implications for climate change, Annu. Rev. Plant Biol. 63 (2012) 637-661.

[19] D. Lombardozzi, J.P. Sparks, G. Bonan, S. Levis, Ozone exposure causes a decoupling of conductance and photosynthesis: implications for the Ball-Berry stomatal conductance model, Oecologia 169 (2012) 651-659.

[20] V.E. Wittig, E.A. Ainsworth, S.L. Naidu, D.F. Karnosky, S.P. Long, Quantifying the impact of current and future tropospheric ozone on tree biomass, growth, physiology and biochemistry: a quantitative meta-analysis, Global Change Biol. 15 (2009) 396-424.

[21] W.J. Manning, Establishing a cause and effect relationship for ambient ozone exposure and tree growth in the forest: progress and an experimental approach, Environ. Pollut. 137 (2005) 443-454.

[22] M.D. Coleman, R.E. Dickson, J.G. Isebrands, D.F. Karnosky, Root growth and physiology of potted and field-grown trembling aspen exposed to tropospheric ozone, Tree Physiol. 16 (1996) 145-152.

[23] D.F. Karnosky, Z.E. Gagnon, R.E. Dickson, M.D. Coleman, E.H. Lee, J.G. Isebrands, Changes in growth, leaf abscission, and biomass associated with seasonal tropospheric ozone exposures of Populus tremuloides clones and seedlings, Can. J. For. Res. 26 (1996) 23-37.

[24] C.P. Andersen, Source-sink balance and carbon allocation below ground in plants exposed to ozone, New Phytol. 157 (2003) 213-228.

[25] J. Ma, The chronology of the "living fossil" Metasequoia glyptostroboides (Taxodiaceae): a review (1943-2003), Harv. Pap. Bot. 8 (2003) 9-18.

[26] Z.Z. Feng, H.Q. Zeng, X.K. Wang, Q.W. Zheng, Z.W. Feng, Sensitivity of Metasequoia glyptostroboides to ozone stress, Photosynthetica 46 (2008) 463-465

[27] T.D. Sharkey, C.J. Bernacchi, G.D. Farquhar, E.L. Singsaas, Fitting photosynthetic carbon dioxide response curves for $C_{3}$ leaves, Plant Cell Environ. 30 (2007) 1035-1040.

[28] S.P. Long, C.J. Bernacchi, Gas exchange measurements, what can they tell us about the underlying limitations to photosynthesis? Procedures and sources of error, J. Exp. Bot. 54 (2003) 2393-2401.

[29] H.K. Lichtenthaler, Chlorophylls and carotenoids: pigments of photosynthetic biomembranes, Methods Enzymol. 148 (1987) 350-382.

[30] W.W. Zhang, Z.Z. Feng, X.K. Wang, J.F. Niu, Responses of native broadleaved woody species to elevated ozone in subtropical China, Environ. Pollut. 163 (2012) 149-157.

[31] M. Watanabe, Y. Hoshika, N. Inada, X.K. Wang, Q.Z. Mao, T. Koike, Photosynthetic traits of Siebold's beech and oak saplings grown under free air ozone exposure in northern Japan, Environ. Pollut. 174 (2013) 50-56.

[32] J. Renaut, S. Bohler, J.F. Hausman, L. Hoffmann, K. Sergeant, N. Ahsan, Y. Jolivet, P. Dizengremel, The impact of atmospheric composition on plants: a case study of ozone and poplar, Mass Spectrom. Rev. 28 (2009) 495-516.

[33] M. Tausz, N.E. Grulke, G. Wieser, Defense and avoidance of ozone under globa change, Environ. Pollut. 147 (2007) 525-531.

[34] E. Paoletti, Ozone slows stomatal response to light and leaf wounding in a Mediterranean Evergreen broadleaf, Arbutus unedo, Environ. Pollut. 134 (2005) 439-445.

[35] Y. Hoshika, G. Carriero, Z.Z. Feng, Y.L. Zhang, E. Paoletti, Determinants of stomatal sluggishness in ozone-exposed deciduous tree species, Sci. Total Environ. 481 (2014) 453-458.

[36] A. Noormets, E.P. McDonald, R.E. Dickson, E.L. Kruger, A. Sôber, J.G. Isebrands, D.F. Karnosky, The effect of elevated carbon dioxide and ozone on leaf-and branch-level photosynthesis and potential plant-level carbon gain in aspen, Trees 15 (2001) 262-270.

[37] Z.Z. Feng, J.F. Niu, W.W. Zhang, X.K. Wang, F.F. Yao, Y. Tian, Effects of ozone exposure on sub-tropical evergreen Cinnamomum camphora seedlings grown in different nitrogen loads, Trees 25 (2011) 617-625.

[38] H. Poorter, Ü. Niinemets, L. Poorter, I.J. Wright, R. Villar, Causes and consequences of variation in leaf mass per area (LMA): a meta-analysis, New Phytol. 182 (2009) 565-588.

[39] F. Bussotti, Functional leaf traits, plant communities and acclimation processes in relation to oxidative stress in trees: a critical overview, Global Change Biol. 14 (2008) 2727-2739. 